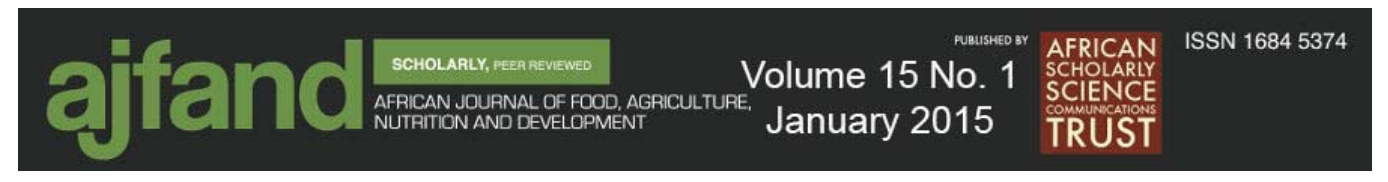

\title{
EFFECT OF MULCH AND DIFFERENT FUNGICIDE SPRAY REGIMES ON YIELD OF TOMATO (SOLANUM LYCOPERSICUM L.) IN TANZANIA
}

\section{Mtui HD ${ }^{1 *}$, Maerere AP ${ }^{1}$, Bennett $\mathrm{MA}^{2}$ and KP Sibuga ${ }^{1}$}

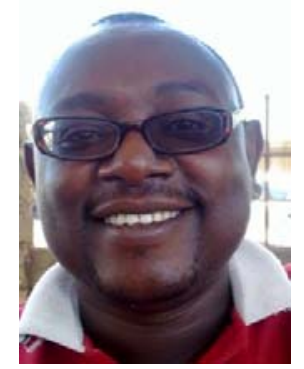

Hosea D. Mtui
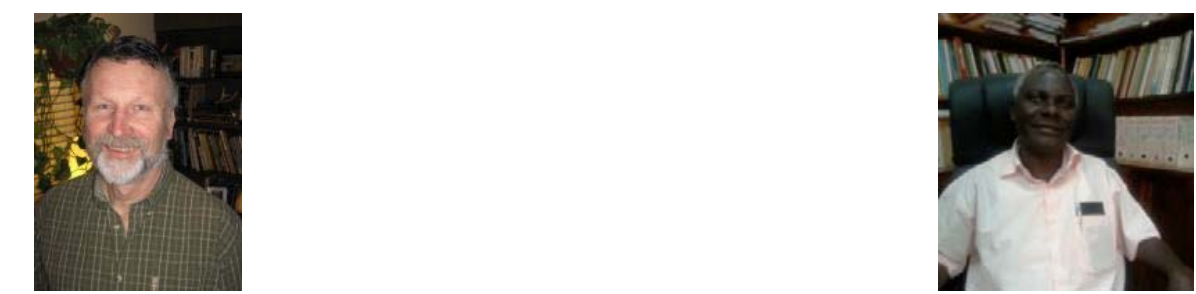

Mark A. Bennett

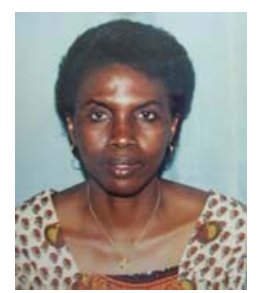

Amon P. Maerere

Kalunde P. Sibuga

*Corresponding Author e-mail: mtuihosea@yahoo.com

${ }^{1}$ Department of Crop Science and Production, Sokoine University of Agriculture, Morogoro, Tanzania. P. O. Box 3005, Chuo Kikuu Morogoro, Tanzania

${ }^{2}$ Department of Horticulture and Crop Science, The Ohio State University, Columbus, OH 43210-1086, USA 


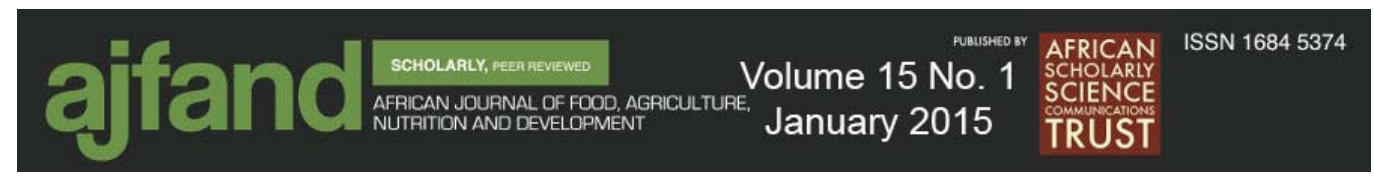

\section{ABSTRACT}

In many areas in Tanzania, pests management for tomato involves weekly pesticide sprays. The practice poses a threat to the environment and health of consumers. In this study the effect of pesticide spray regimes and use of mulch were evaluated on 'Tanya VF' and 'Tengeru 97' tomato varieties. Field experiment consisting of a $2 \times 2 \times 4$ factorial arrangement in a split-split plot design with three replications was conducted at Sokoine University of Agriculture, Morogoro (6 $6^{\circ} 05^{\prime} \mathrm{S}, 35^{\circ} 37^{\prime} \mathrm{E}$ and $525 \mathrm{~m}$ above sea level). Treatment factors comprised two varieties (main plot factor), mulching/number of mulching (subplot factor) and three fungicide spray regimes (sub subplot factor). Results showed that the spray regimes: farmers' practice (FP), Integrated Pests Management (IPM) based on pests scouting, sprays based on manufacturers' recommendation (MR); produced significantly more fruits per plant and higher fruit weight compared to the control. There was no significant difference $(p<0.05)$ between FP, IPM and MR on fruit yield parameters. The results further revealed that use of mulch significantly led to higher fruit number per plant $(p=0.020)$. Although average fruit weight was similar $(\mathrm{p}<0.05)$, other marketable fruit yield parameters were statistically different between mulched and non-mulched plots $(\mathrm{p}=0.007)$. 'Tanya VF' had consistently higher yields compared to 'Tengeru 97'. Fungicide sprays were statistically different to the control with respect to blossom end $\operatorname{rot}(\mathrm{p}=0.002)$, fruit rot $(\mathrm{p}<0.001)$ and percentage of non-marketable yield $(\mathrm{p}=0.001)$. Mulching significantly reduced American bollworm and blossom end $\operatorname{rot}(p=0.012, p=0.003$, respectively). The major contributor to tomato fruit loss was Blossom End Rot (BER) and Fruit Rot for 'Tengeru 97' and 'Tanya VF', respectively. It is evident, therefore, that: a proper combination of tomato cultural management practices can significantly reduce the use of pesticides, and improve tomato fruit quality and marketable yield which would increase profit margin accrued by farmers.

Key words: IPM, marketable yield, mulch, tomato 


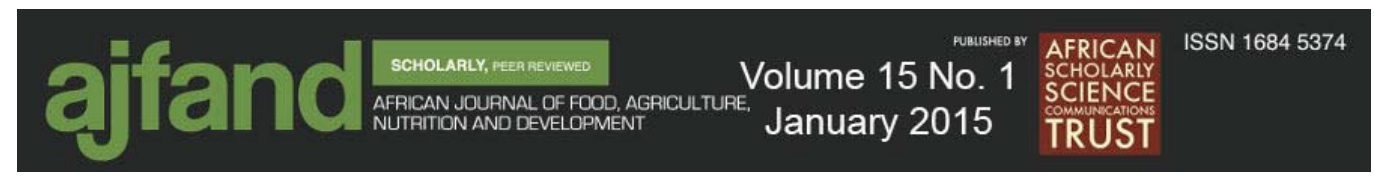

\section{INTRODUCTION}

Tomato (Solanum lycopersicum L) is one of the most important vegetable crops in Tanzania. Total annual production is estimated to be more than 235,000 tons [1]. Tomato yields in the tropics vary widely $(1-23 \mathrm{t} / \mathrm{ha})$ compared to those in temperate regions, where yields of $10-22 \mathrm{t} / \mathrm{ha}$ can be realized [2]. Recent survey results in Morogoro Region, eastern Tanzania, indicate that under current management practices, tomato yields vary from 2.2 to $16.5 \mathrm{t} / \mathrm{ha}$; the differences were ascribed to cultural practices, pests prevalence and pests management [3].

Tomato production in Morogoro Region is mainly undertaken by resource limited small-scale farmers who do not use mulch but do apply fungicides on a weekly basis, sometimes using a combination or 'cocktail' of fungicides $[4,5]$. This injudicious use of fungicides is provoked by high percent of the produce being lost to a variety of causes with fruit rot accounting for the majority of tomato fruit losses [3]. Use of pesticides beyond the recommended dosage and frequency as a measure to reduce postharvest loss can lead to residues in the fruit that may cause consumer health hazards. This also increases the cost of production and reduces profit margins. It is, therefore, important to design and disseminate Integrated Pests Management (IPM) strategies that can be utilized by the small-scale farmers.

Most tomato production in Tanzania occurs during the dry season but some farmers prefer to grow tomato during the rainy season because the crop requires adequate moisture. Dry season production is associated with low fruit yields attributed to poor fruit set. Dry season tomato production is mainly practiced in valley areas for the crop to utilize residual moisture in the soil. Most farmers grow tomatoes in dry season due to relatively lower incidence of fungal diseases, less labour competition and land availability after harvest of the major crops (mainly maize and rice). During dry season, production is highly limited by low moisture availability in the soil as in most cases residual moisture is utilized $[3,6]$. The low soil moisture availability in the soil requires moisture conservation techniques, such as mulching, to conserve the available moisture for crop utilization.

The use of appropriate cultural practices can enhance productivity of the crop leading to increased profits [6]. Mulching is known to be beneficial because it increases water availability duration and nutrient uptake. It also reduces contact between tomato fruits and the soil, which in turn reduces fruit rot. Mulching also reduces aphid populations, the incidence and severity of early and late blights, fruit cracking, blossom end rot, fruit worm infestation, and Alternaria stem canker on tomato $[6,7,8]$. Mulching significantly improved tomato fruit weight and fruit number per plant, reduced fruit rot and increase the proportion of marketable fruit yield [5]. Mulch had significant effects on growth and yield components of tomato. Dry grass mulch moderates soil temperature, retards the loss of soil moisture and checks weed growth, all of which are important factors contributing to increased crop production $[4,9,10,11]$. They also found that yield was higher in mulched tomato than non-mulched plants due to favorable soil conditions and reduction of foliar diseases. By applying straw mulch, the plants flowered and produced fruits later and had longer harvesting period than those in non-mulched plots. Similar 


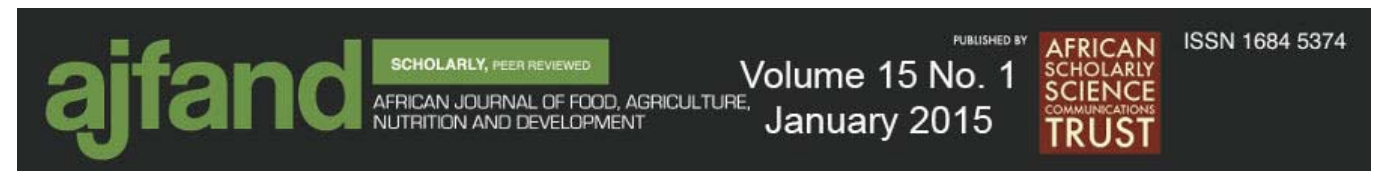

results were obtained by other researchers $[5,11,12]$. The authors found that mulching with dry grass delayed the onset of flowering due to enhanced vegetative growth and which led to higher yield compared to tomato grown on bare ground [12]. This suggested that the yield increment results from favourable temperature and soil moisture created by mulching. In comparison, increased soil temperature and lower soil moisture experienced by plants grown on bare ground can lead to hastened plant maturity, increased flower abortion, inadequate photosynthates supply and increased intensities of moisture deficits in the season all of which result in reduced productivity [12].

The main objective of this study was to assess the effects of different management practices on tomato yield and the major causes of tomato fruit loss.

\section{MATERIALS AND METHODS}

Determinate and semi indeterminate tomato varieties 'Tanya VF' and 'Tengeru 97', respectively were used in this experiment. Seedlings were raised at the Horticultural Unit at Sokoine University of Agriculture (SUA-HU), Morogoro $\left(6^{\circ} 05^{\prime} \mathrm{S}, 35^{\circ} 37^{\prime} \mathrm{E}\right.$ and $525 \mathrm{~m}$ above sea level). The experiment was conducted in dry season (July September). Seedlings were pricked 5 days after emergence and grown on soil blocks $(5 \mathrm{~cm} \times 5 \mathrm{~cm} \times 5 \mathrm{~cm})$ made from composted yard wastes. The seedlings were raised in a high plastic tunnel with sunscreen netting which allowed $60 \%$ of the sunlight to pass through. Seedlings were then transplanted to the field 3 weeks after pricking. The field experiment was conducted at the Crop Museum Unit of the Sokoine University of Agriculture (SUA-CMU). The experimental layout was a $2 \times 2 \times 4$ factorial arrangement in a split-split plot design with three replications. The treatment factors were variety (main factor), mulching (subplot factor) and fungicide spray regimes (sub-subplot factor). Plots of $420 \mathrm{~cm} \times 280 \mathrm{~cm}$ were prepared using hand hoe. Seedlings were transplanted into the plots at a spacing of $70 \mathrm{~cm}$ between rows and $70 \mathrm{~cm}$ between plants with four rows giving 24 plants per plot. Three fungicide application programs were tested: 1. plots sprayed weekly (farmers' practice - FP), 2. sprayed when weather conditions were favourable for disease development and or insect pests at threshold levels found after scouting (IPM) and 3. sprayed as per the manufacturers' recommendation (MR). Unsprayed plots (F0) were included as a control. Fungicide, Ridomil GOLD ${ }^{\circledR}$ (Mancozeb + Metalaxyl), which was commonly used for tomato production in Morogoro was used in this experiment. For FP, MR and IPM the fungicide was sprayed 14, seven and four times, respectively. Selecron ${ }^{\circledR}$ (Profenofos), a broad spectrum insecticide, was used to control insect pests.

Mulching was done using dry grass (Panicum spp.). The grass was cut before flowering, sundried and chopped to approximately $25 \mathrm{~cm}$ long. The mulch was then laid down by hand at a thickness of $10 \mathrm{~cm}$, making sure the soil was completely covered three days after transplanting. Compound fertilizer in the form of NPK (20:18:18) was top-dressed at a rate of $20 \mathrm{kgN} \mathrm{ha}^{-1}$ two weeks after transplanting and at fruit-set stage. Plants were irrigated individually with water pumped from a nearby reservoir once a week using a hose pipe with a shower nozzle attached at the end. Yield estimates were made based on harvests from eight plants from the middle two rows of each plot. Fruits were 


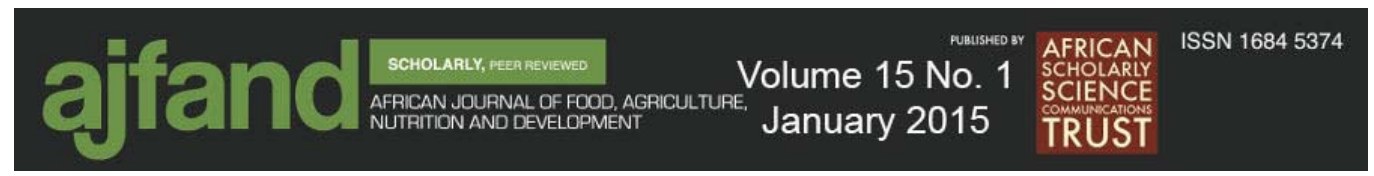

harvested in the morning and sorting was done by the same two people for all harvests. Fruits affected by rot, birds and bollworm were recorded and discarded. Marketable yield was calculated based on fruit quality standards acceptable by the local market tomato vendors.

Data analysis was carried out using Genstat v.3 Statistical package (VSN International, U.K). Analysis of variance (ANOVA) was performed and when significant differences existed $(p=0.05)$, the Least Significant Difference (LSD; $\alpha=0.05)$ test was used as a means separation procedure.

\section{RESULTS}

Marketable tomato fruit yield and yield components were statistically higher when any of fungicide regimes was applied compared to the control (Table 1). Plants sprayed using any of the three spray regimes $(F P$, IPM, MR) produced more fruits $(p<0.001)$ and higher fruit weight $(\mathrm{p}<0.001)$ compared to control $(\mathrm{F} 0)$. There were no statistical differences $(p=0.05)$ between the FP, IPM and MR spray regimes on yield, yield components and percentage of marketable fruits (Table 1).

Results in Table 2 reveal that, the use of mulch led to plants that produced more fruits $(\mathrm{p}=0.020)$ than non-mulched plants. Although the average fruit weight was similar $(\mathrm{p}$ $=0.05)$, the average marketable yield per harvest, marketable yield per hectare and the percentage of marketable produce was higher $(\mathrm{p}=0.007, \mathrm{p}=0.019, \mathrm{p}=0.002$, respectively) where mulch was used compared to non-mulched plots.

'Tengeru 97', a semi-indeterminate cultivar, was less productive than 'Tanya VF' (Table 3). 'Tanya VF' had consistently higher number of marketable fruits per plant ( $p$ $=0.003)$, marketable yield per harvest $(\mathrm{p}=0.020)$, total and percentage marketable yield ( $\mathrm{p}=0.039$ and $\mathrm{p}=0.015$, respectively). However, 'Tangeru 97' had a higher average fruit weight compared to that of 'Tanya VF' (Table 3).

There were statistically different results between the three fungicide spray regimes compared to the control with respect to blossom end $\operatorname{rot}(\mathrm{p}=0.002)$ fruit $\operatorname{rot}(\mathrm{p}<0.001)$ and the percentage non marketable yield $(\mathrm{p}=0.001)$. However, the three fungicide spray regimes were statistically similar $(p=0.05)$ [Table 4].

Mulching significantly reduced American bollworm damage, BER, fruit rot and the percentage non marketable produce $(\mathrm{p}=0.012, \mathrm{p}=0.003, \mathrm{p}=0.019$, respectively) [Table 5]. When mulch was used, approximately $19 \%$ of the produce was discarded while without mulch $29 \%$ of the fruits were rendered unmarketable (Table 5).

According to results in Table 6, 'Tengeru 97' had a higher percentage of non marketable fruit weight $(31 \%)$ than 'Tanya VF' $(16.7 \%)$. The major contributor to fruit loss for 'Tengeru 97' variety was BER while fruit rot was the major cause of produce loss for 'Tanya VF' variety. It was also found that birds preferred variety 'Tengeru 97' fruits compared to 'Tanya VF'. The loss due to fruit rot was different between varieties $(\mathrm{p}=$ 


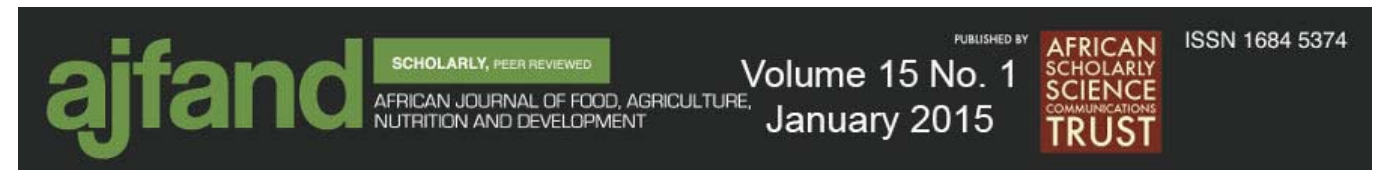

0.003). 'Tanya VF' had a higher quantity of fruit rot compared to 'Tengeru 97' (Table $6)$.

\section{DISCUSSION}

This study demonstrates that the prevailing farmer practices led to increased production costs and consequently reduced incomes. Since the yield and yield components were similar when FP, IPM and MR spray regimes were compared (Table 1), spraying beyond MR is discouraged. The effect of MR, FP and IPM spray regimes on tomato fruit loss was similar (Table 4). This suggests that, the frequency of spraying is not related to increased tomato harvest and strengthens the justification for IPM promotion. This also confirms our earlier reports that the current farmers' practice for insect pests and disease control in tomatoes based on routine weekly sprays is not always required [4]. It is inevitable therefore to train farmers on IPM strategies to lessen pesticide use which will be good to the environment, farmers, and consumers. With good scouting knowledge, it is possible to reduce the number of sprays currently used by farmers from more than 16 times (FP) to four times per crop cycle (IPM).

The higher value for BER disorder recorded for the three fungicide spray regimes compared to the control could have resulted from the higher fruit yield by the enhanced fruit number and size produced by fungicide sprayed plants. Since BER is a physiological disorder caused by local deficiency in calcium $[13,14]$ where fungicides were sprayed resulted into plants which produced more fruits and fruits with larger size (Table 1). The high produce loss caused by BER may be attributable to reduced calcium availability for the given number and size of fruits per plant. Allocation of the calcium absorbed from the soil could have been unsatisfactory for the given number and size of fruits per plant. This calls for application of calcium based fertilizer (such as Calcium Ammonium Nitrate) during the growing season to increase the available calcium in the soil for plant uptake and consequently reduce BER disorder.

Mulching has been shown to be a beneficial practice in tomato production. These current results are in accordance with previous findings which revealed that, fruit yield components were consistently improved for plants grown in mulched plots compared to tomato crops grown on bare soil [5]. Tomato plants grown in mulched plots produced a higher number of fruits per plant, larger fruits, leading to higher marketable yield (Table 2). These findings have also been observed by several researchers when studying the effect of mulches on growth, yield components and yield of tomato $[6,10,12]$. The reduction in percentage of non-marketable fruits from plants grown in mulched plots is another important effect of mulching. The use of dry grass mulch can, therefore, improve yield (Table 2) and reduce tomato fruit loss (Table 5). Current results support the concept that mulching regulates soil moisture regime, enhances calcium uptake and reduces evaporative heat thereby reducing the BER problem. The reduction of fruit rot may be due to the fact that in mulched plots, fruit contact with the soil is minimized. This keeps the fruits away from soil borne pathogens, abrasion from soil particles as well as soil heat. It is, therefore, important to use mulch as a way of increasing marketable tomato fruits. Mulching is, therefore, a good component of IPM package for tomato production. 


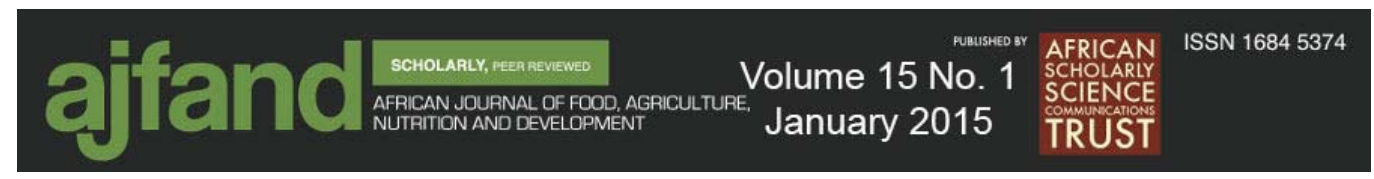

Different varieties are likely to have differences in yield and yield components as well as fruit loss due to various causes. 'Tanya VF, yielded higher compared to 'Tengeru 97'. Although variety 'Tengeru 97' had larger fruits, variety 'Tanya VF' had more fruit number per plant and also higher marketable yield (Table 3 ). Fruit damage by birds was higher in 'Tengeru 97' compared to 'Tanya VF' (Table 6). This may be due to difference in growth form between the two varieties. 'Tengeru 97' is semiindeterminate variety and was staked while 'Tanya VF' is bushy and determinate. It was therefore easier for birds to see and attack the fruits on 'Tengeru 97' than on 'Tanya VF' which is determinate hiding the fruits in the dense bushy canopy. The major contributor to fruit loss for 'Tengeru 97' was BER, while for 'Tanya VF' was fruit rot. This may also be due to the growth form differences between the two varieties. 'Tanya VF' fruits are more likely to be in contact with the soil causing higher incidence of fruit rot. The results in Table 5 support this proposition.

\section{CONCLUSION}

In Tanzania, tomato is the leading vegetable in terms of production and area under cultivation followed by cabbage, onion and carrot (FAO, 2010). Excessive fungicide sprays application is among constraints in tomato production in Tanzania. Farmers in most tomato growing areas in the country employ a routine weekly fungicide spray regime to combat fungal diseases $[3,4]$. This practice has been shown to give neither additional yield nor improved tomato fruit quality. This study has shown that a fourtime fungicide application regime per crop cycle is adequate to obtain optimum tomato fruit yield and quality similar to weekly sprays. Heavy application of pesticides is harmful to the farmers, consumers and also affects the environment. Heavily sprayed produce are of limited market opportunities especially for export market where maximum residue levels have been established. Pesticide contaminated produce are also unsuitable for processing. A proper combination of tomato cultural management practices and the use of integrated pests management can significantly reduce use of pesticides and improve quantity of marketable tomato yield. This will increase profit margins obtained by farmers while availing a safer produce to consumers. The use of mulch and application of pesticides according to the recommended rates only as necessitated by the likelihood of disease occurrence or pests damage constitute good components of IPM strategies for tomato. Adoption of IPM strategies will reduce health risks to tomato farmers and consumers, reduce production costs and ultimately increase profit. 


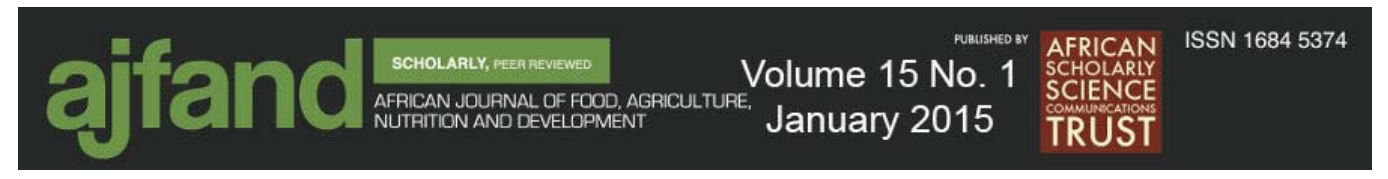

\section{ACKNOWLEDGEMENT}

This paper was supported by funding from U.S. Agency for International Development through the Integrated Pests Management - Collaborative Research Support Program (IPM - CRSP) [Award No. EPP-A-00-04-00016-00]. The opinions expressed herein are those of the authors and do not necessarily reflect the views of the U.S. Agency for International Development. 


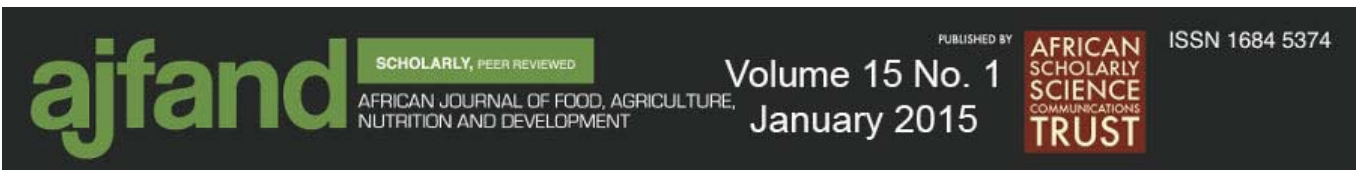

Table 1: Effect of different spray regimes on marketable tomato yield and yield components

\begin{tabular}{lccccc}
\hline \multirow{2}{*}{$\begin{array}{l}\text { Spray } \\
\text { regimes }\end{array}$} & $\begin{array}{l}\text { Marketable } \\
\text { fruits number } \\
\text { plant }^{-1}\end{array}$ & $\begin{array}{l}\text { Average } \\
\text { fruit wt }(\mathrm{g})\end{array}$ & $\begin{array}{l}\text { Marketable yield }_{\text {harvest }^{-1}(\mathrm{t} / \mathrm{ha})} \\
\text { nyyyyyy}\end{array}$ & $\begin{array}{l}\text { Yield } \\
(\mathrm{t} / \mathrm{ha})\end{array}$ & $\begin{array}{l}\text { \% Marketable } \\
\text { yield }\end{array}$ \\
\hline Control & $3.69^{\mathrm{a}}$ & $74.5^{\mathrm{a}}$ & $2.67^{\mathrm{a}}$ & $10.70^{\mathrm{a}}$ & $66.5^{\mathrm{a}}$ \\
IPM & $7.12^{\mathrm{b}}$ & $102.3^{\mathrm{b}}$ & $6.61^{\mathrm{b}}$ & $23.96^{\mathrm{b}}$ & $79.2^{\mathrm{b}}$ \\
FP & $6.21^{\mathrm{b}}$ & $105.6^{\mathrm{b}}$ & $5.98^{\mathrm{b}}$ & $23.92^{\mathrm{b}}$ & $79.9^{\mathrm{b}}$ \\
MR & $6.44^{\mathrm{b}}$ & $103.8^{\mathrm{b}}$ & $6.32^{\mathrm{b}}$ & $24.26^{\mathrm{b}}$ & $79.2^{\mathrm{b}}$ \\
LSD & 0.85 & 9.54 & 0.76 & 4.08 & 7.04 \\
$p$-value & $<0.001$ & $<0.001$ & $<0.001$ & $<0.001$ & 0.001 \\
\hline
\end{tabular}

Means within a column followed by the same superscript are not different $(\mathrm{p}<0.05)$; $\mathrm{t} / \mathrm{ha}=$ Tons per hectare;

LSD $=$ Least significant difference

Table 2: Effect of mulch and no-mulch treatments on marketable tomato yield and yield components

\begin{tabular}{|c|c|c|c|c|c|}
\hline \multirow[b]{2}{*}{ Mulch } & \multicolumn{5}{|c|}{ Yield and yield components } \\
\hline & $\begin{array}{l}\text { Marketable } \\
\text { fruit number } \\
\text { plant }^{-1}\end{array}$ & $\begin{array}{l}\text { Average } \\
\text { fruit wt (g) }\end{array}$ & $\begin{array}{l}\text { Marketable } \\
\text { yield harvest }{ }^{-1} \\
\text { (t/ha) }\end{array}$ & Yield (t/ha) & $\begin{array}{l}\text { \% Marketable } \\
\text { yield }\end{array}$ \\
\hline $\begin{array}{l}\text { Without } \\
\text { Mulch }\end{array}$ & $5.22^{\mathrm{a}}$ & 91.3 & $4.63^{\mathrm{a}}$ & $17.78^{\mathrm{a}}$ & $71^{\mathrm{a}}$ \\
\hline With Mulch & $6.51^{b}$ & 101.8 & $6.16^{\mathrm{b}}$ & $23.64^{\mathrm{b}}$ & $81^{b}$ \\
\hline LSD & 0.96 & 17.47 & 0.85 & 2.37 & 7.27 \\
\hline$p$-value & 0.020 & $0.173^{\mathrm{NS}}$ & 0.007 & 0.002 & 0.019 \\
\hline
\end{tabular}

Means within a column followed by the same superscript are not different $(\mathrm{p}<0.05) ; \mathrm{t} / \mathrm{ha}=$ Tons per hectare;

LSD $=$ Least significant difference; NS $=$ Non significant 


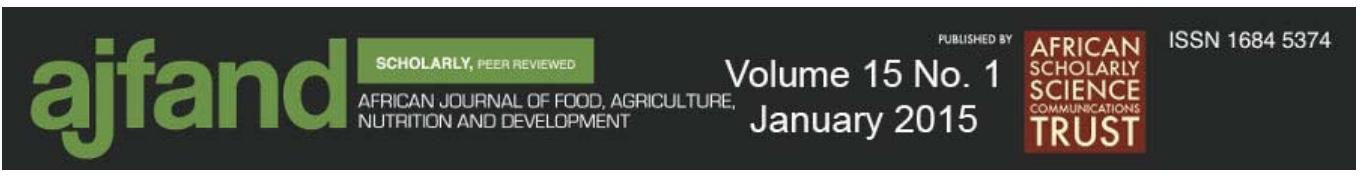

Table 3: Marketable tomato yield and yield components for varieties 'Tanya VF' and 'Tengeru 97'

\begin{tabular}{lccccc}
\hline & \multicolumn{5}{c}{ Yield and yield components } \\
\cline { 2 - 6 } Variety & $\begin{array}{l}\text { Marketable } \\
\text { fruit number } \\
\text { plant }^{-1}\end{array}$ & $\begin{array}{l}\text { Average } \\
\text { fruit wt } \\
(\mathrm{g})\end{array}$ & $\begin{array}{l}\text { Marketable yield }_{\text {harvest }^{-1}(\mathrm{t} / \mathrm{ha})} \\
\text { Yield } \\
(\mathrm{t} / \mathrm{ha})\end{array}$ & $\begin{array}{l}\text { \% Marketable } \\
\text { yield }\end{array}$ \\
\hline 'Tanya VF' & $8.77^{\mathrm{a}}$ & $78.1^{\mathrm{a}}$ & $7.08^{\mathrm{b}}$ & $27.50^{\mathrm{b}}$ & $83^{\mathrm{b}}$ \\
'Tengeru & $2.96^{\mathrm{b}}$ & $115.0^{\mathrm{b}}$ & $3.71^{\mathrm{a}}$ & $13.92^{\mathrm{a}}$ & $69^{\mathrm{a}}$ \\
97 & 1.36 & 13.74 & 2.09 & 11.88 & 7.56 \\
LSD & 0.003 & 0.007 & 0.020 & 0.039 & 0.015 \\
$p$-value & & & & & \\
\hline
\end{tabular}

Means within a column followed by the same superscript are not different $(\mathrm{p}<0.05) ; \mathrm{t} / \mathrm{ha}=$ Tons per hectare;

LSD $=$ Least significant difference

Table 4: Effect of different spray regimes on tomato fruit loss

\begin{tabular}{|c|c|c|c|c|c|c|}
\hline \multirow{2}{*}{$\begin{array}{l}\text { Spray } \\
\text { regimes }\end{array}$} & \multicolumn{4}{|c|}{ Cause of produce loss (t/ha) } & \multicolumn{2}{|c|}{$\begin{array}{l}\text { Non-marketable yield } \\
\text { components }\end{array}$} \\
\hline & $\begin{array}{l}\text { American } \\
\text { Bollworm }\end{array}$ & Birds & $\begin{array}{l}\text { Blossom } \\
\text { End Rot }\end{array}$ & Fruit rot & $\begin{array}{l}\text { Non } \\
\text { marketable } \\
\text { fruit weight ha } \\
{ }^{1}(\mathrm{t} / \mathrm{ha})\end{array}$ & $\begin{array}{l}\% \text { Non } \\
\text { marketable } \\
\text { yield }\end{array}$ \\
\hline Control & 0.45 & 0.60 & $1.20^{\mathrm{a}}$ & $3.64^{\mathrm{a}}$ & 5.89 & $34^{\mathrm{a}}$ \\
\hline IPM & 0.54 & 0.87 & $2.12^{\mathrm{b}}$ & $1.50^{\mathrm{b}}$ & 5.03 & $21^{\mathrm{b}}$ \\
\hline FP & 0.55 & 0.96 & $2.18^{\mathrm{b}}$ & $1.45^{\mathrm{b}}$ & 5.13 & $20^{\mathrm{b}}$ \\
\hline MR & 0.68 & 0.71 & $2.22^{\mathrm{b}}$ & $1.67^{\mathrm{b}}$ & 5.29 & $21^{\mathrm{b}}$ \\
\hline LSD & 0.32 & 0.28 & 0.56 & 0.92 & 1.29 & 7.04 \\
\hline$p$-value & $0.548^{\mathrm{NS}}$ & $\underset{\mathrm{S}}{0.073^{\mathrm{N}}}$ & 0.002 & $<0.001$ & $0.531^{\mathrm{NS}}$ & 0.001 \\
\hline
\end{tabular}

Means within a column followed by the same superscript are not different $(\mathrm{p}<0.05) ; \mathrm{t} / \mathrm{ha}=$ Tons per hectare;

$\mathrm{LSD}=$ Least significant difference; NS $=$ Non significant 


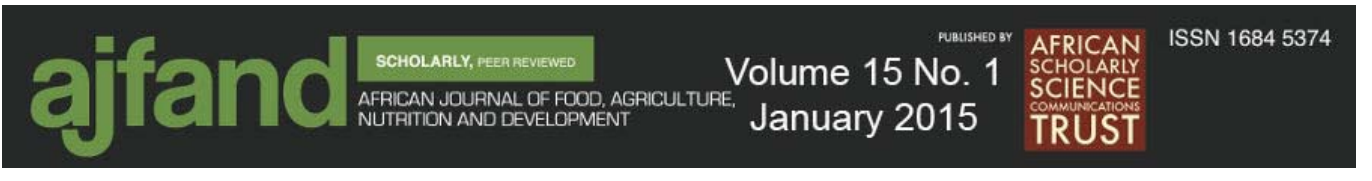

Table 5: The effect of mulch on tomato fruit loss

\begin{tabular}{|c|c|c|c|c|c|c|}
\hline \multirow{2}{*}{ Mulching } & \multicolumn{4}{|c|}{ Cause of produce loss (t/ha) } & \multicolumn{2}{|c|}{$\begin{array}{c}\text { Non-marketable yield } \\
\text { components }\end{array}$} \\
\hline & $\begin{array}{l}\text { American } \\
\text { Bollworm }\end{array}$ & Birds & $\begin{array}{l}\text { Blossom } \\
\text { End Rot }\end{array}$ & Fruit rot & $\begin{array}{l}\text { Non } \\
\text { marketable } \\
\text { fruit weight } \\
\mathrm{ha}^{-1}(\mathrm{t} / \mathrm{ha})\end{array}$ & $\begin{array}{l}\% \text { Non } \\
\text { marketable } \\
\text { yield }\end{array}$ \\
\hline $\begin{array}{l}\text { Without } \\
\text { mulch }\end{array}$ & $0.61^{\mathrm{b}}$ & 0.86 & $3.63^{b}$ & $2.58^{b}$ & $6.49^{\mathrm{b}}$ & $28.8^{b}$ \\
\hline With mulch & $0.50^{\mathrm{a}}$ & 0.71 & $0.23^{\mathrm{a}}$ & $1.56^{\mathrm{a}}$ & $4.18^{\mathrm{a}}$ & $18.8^{\mathrm{a}}$ \\
\hline LSD & 0.07 & 0.29 & 0.38 & 0.45 & 0.31 & 7.27 \\
\hline$p$-value & 0.012 & $\begin{array}{c}0.250 \\
\text { NS }\end{array}$ & $<0.001$ & 0.003 & $<0.001$ & 0.019 \\
\hline
\end{tabular}

Means within a column followed by the same superscript are not different $(\mathrm{p}<0.05) ; \mathrm{t} / \mathrm{ha}=$ Tons per hectare;

LSD $=$ Least significant difference; NS = Non significant

Table 6: Varietal comparison on attack by different causes of tomato fruit loss

\begin{tabular}{lcccccc}
\hline \multirow{2}{*}{ Variety } & \multicolumn{3}{c}{ Cause of produce loss (t/ha) } & \multicolumn{2}{c}{$\begin{array}{c}\text { Non-marketable yield } \\
\text { components }\end{array}$} \\
\cline { 2 - 7 } & $\begin{array}{l}\text { American } \\
\text { Bollworm }\end{array}$ & Birds & $\begin{array}{l}\text { Blossom } \\
\text { End Rot }\end{array}$ & $\begin{array}{l}\text { Fruit } \\
\text { rot }\end{array}$ & $\begin{array}{l}\text { Non marketable } \\
\text { fruit weight } \\
(\mathrm{t} / \mathrm{ha})\end{array}$ & $\begin{array}{l}\text { \%on } \\
\text { marketable } \\
\text { yield }\end{array}$ \\
\hline 'Tanya VF' & $0.12^{\mathrm{a}}$ & $0.33^{\mathrm{a}}$ & $0.23^{\mathrm{a}}$ & $3.64^{\mathrm{b}}$ & $4.33^{\mathrm{a}}$ & $17^{\mathrm{a}}$ \\
'Tengeru 97' & $0.99^{\mathrm{b}}$ & $1.24^{\mathrm{b}}$ & $3.63^{\mathrm{b}}$ & $0.49^{\mathrm{a}}$ & $6.34^{\mathrm{b}}$ & $31^{\mathrm{b}}$ \\
LSD & 0.41 & 0.29 & 0.72 & 0.68 & 0.36 & 7.56 \\
$p$-value & 0.012 & 0.005 & 0.002 & 0.003 & 0.002 & 0.015 \\
\hline
\end{tabular}

Means within a column followed by the same superscript are not different $(\mathrm{p}<0.05) ; \mathrm{t} / \mathrm{ha}=$ Tons per hectare;

LSD = Least significant difference; NS = Non significant 


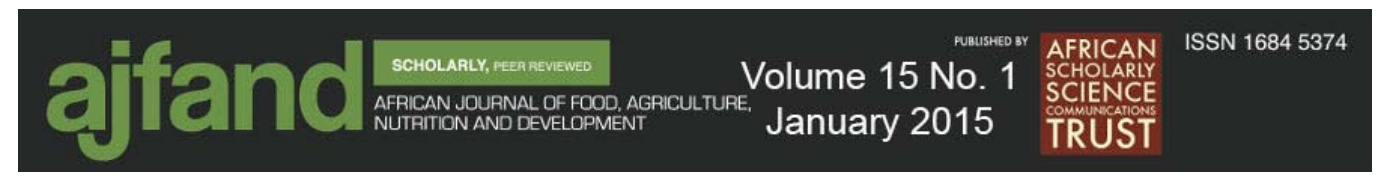

\section{REFERENCES}

1. FAO. http://faostat.fao.org/site/567/DesktopDefault.aspx?PageID=567\#ancor 2010; site visited on 13-12-2012.

2. Lanny G Fruit vegetables. In: Raemaekers RH (Ed), Crop Production in Tropical Africa. Brussels, 2001.

3. Maerere AP, Sibuga KP, Mwajombe KK, Bulali J, William AN, Mwinyipembe L, Mbwambo $\mathbf{J}$ and $\mathbf{J}$ Shayo Baseline Survey Report of Tomato Production in Mvomero district, Morogoro Region, Tanzania. Regional IPM Program for East Africa: Kenya, Tanzania and Uganda 2006; Unpublished pp.21.

4. Maerere AP, Sibuga KP, Bulali JEM, Mwatawala MW, Kovach J, Kyamanywa S, Mtui HD and M Erbaugh Deriving appropriate pests management technologies for smallholder tomato (Solanum lycopersicum L.) growers: A case study of Morogoro, Tanzania. J. Ani. and Plant Sci. 2010; 6 (3): $663-676$.

5. Mtui, HD, Bennett MA, Maerere AP, Miller SA, Kleinhenz MD and KP Sibuga Effect of seed treatments and mulch on seedborne bacterial pathogens and yield of tomato (Solanum lycopersicum L.) in Tanzania. J. Ani. and Plant Sci. 2010; 8 (3): 1006- 1015.

6. Rwezaula JW, Mulungu SL, Ishengoma CG, Reuben SOWM, Msolla SN, Maerere AP, Njau PJR, Ashimogo GC, Tiisekwa T, Mvena T and HS Laswai Effect of organic mulch types on common biotic and abiotic factors and components of yield in determinate and indeterminate tomato (Lycopersicon esculentum Mill.) commercial cultivars. Asian J. Plant Sci. 2005; 4:580-588.

7. Akemo MC, Regnier EE and MA Bennett Weed suppression in spring-sown rye (Secale cereale)-pea (Pisum sativum) cover crop mixes Weed Tech. 2000; 14 (3): 545-549.

8. Lyimo HFJ, Maerere AP, Njau PR and TDM Tiluhongelwa The effect of mulching and staking on the development of early and late blights of tomato. Tanzania J. Agric. Sci. 1998; 1: 167-172.

9. Ramakrishna A, Tam HM, Wani SP and TD Long Effect of mulch on soil temperature, moisture, weed infestation and yield of groundnut in northern Vietnam. Field Crops Res. 2005; 95: 115-125.

10. Ramalan AA and CU Nwokeocha Effects of furrow irrigation methods, mulching and soil water suction on the growth, yield and water use efficiency of tomato in the Nigerian Savanna. Agric. Water Manag. 2000; 45: 317-330. 


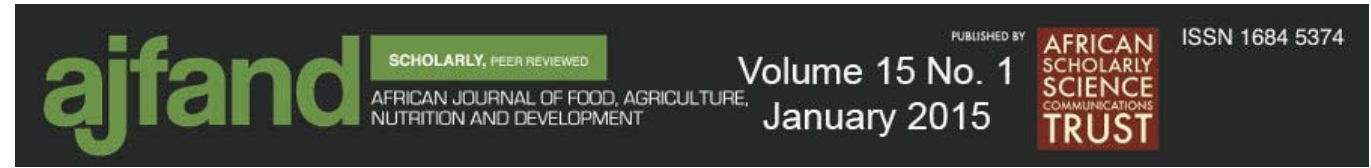

11. Vos JGM, Uhan TS and R Sutarya Integrated crop management of hot pepper (Capsicum spp) under tropical lowland conditions: Effect of rice straws and plastic mulch on crop health. Crop Prot. 1995; 4: 445-452.

12. Agele SO, Iremiren GO and SO Ojeniyi Effects of plant density and mulching on the performance of late-season tomato (Lycopersicon esculentum) in southern Nigeria. J. Agric. Sci. Cambridge 1999; 133, 397-402.

13. Abdel-Mawgoud AMR, El-Abd SO, Abou-Hadid AF and YN Sassine Blossom end rot of sweet pepper fruits in relation to different shoot and root conditions. Asian J. Plant Sci. 2005; 4: 619-624.

14. Ho LC, Brown M, Andrews $\mathbf{J}$ and $\mathbf{P}$ Adams Uptake and transport of calcium and the possible causes of blossom end rot in tomato. J. Exper. Bot. 1993; 44: 509-518. 